\title{
The Ecological and Geographical Analysis And Modeling of Spatial Distribution of Zabrus Tenebrioides Goeze with the Help of Geoinformational Systems
}

\author{
Avtaeva T.A. \\ Department of biological research \\ Kh. Ibragimov Complex Institute of the Russian Academy \\ of Sciences \\ Grozny, Russia \\ avtaeva1971@mail.ru
}

\author{
Kushalieva Sh. A. \\ Department of biology and teaching methodology \\ Chechen state pedagogical university \\ Grozny, Russia \\ hemiptera2013@mail.ru
}

\author{
Skripshincky A.V. \\ department of social and economic geography, geoinformatics and tourism \\ North-Caucasus Federal University \\ Stavropol, Russia \\ ron1975@list.ru
}

\begin{abstract}
The article with the help of the methods of geoinformation modeling determined the extent to which the conditions of different territories of the world are suitable for the habitat of Zabrus tenebrioides according to climatic parameters. The research is performed according to the data from 279 points obtained from our own collections, the Global Biodiversity Information Facility database and literary sources. With the usage of the MaxEnt 3.4.1 program, maps of the most probable areas of Zabrus tenebrioides distribution were created and the contribution of each of the 19 bioclimatic parameters obtained from the open WorldClim database was determined. The factors that have the greatest influence on the spread of the Zabrus tenebrioides are determined. The analysis of the spatial distribution of the studied species was carried out on the basis of a raster of the sum of effective temperatures from the Open Geographic Information System (OGIS) database. The main climatic factors affecting the distribution of Zabrus tenebrioides are: average annual air temperature, average daily temperature amplitude for each month, isothermality, and standard deviation of temperatures, maximum temperature of the warmest month, and minimum temperature of the coldest month of the year. According to the field research materials, the life cycle of the Zabrus tenebrioides in the conditions of the steppe zone of the Chechen Republic is described.
\end{abstract}

Keywords - life cycle, geoinformational technologies, model, spatial distribution, Zabrus tenebrioides, bioclimatic parameters

\section{INTRODUCTION}

Zabrus tenebrioides is a small beetle of the type of Zabrus of the ground beetle family (Coleoptera, Carabidae), characterized by wide distribution. The distribution of this species extends from England and southern Sweden to North
Africa and Asia Minor. In Russia, it is distributed in almost all southern areas of grain cultivation, including the Caucasus, where it usually feeds on wild-growing and cultivated cereals. Often found in the countries of Former Soviet Republics, including Kazakhstan, Ukraine and Belarus. This species is very numerous in the Volga and Central Black Earth regions.

Zabrus tenebrioides is a dangerous pest of cereals. It is able to cause great damage to crops of barley, wheat, rye, and corn. Both the beetle themselves and their worms are harmful.

The distribution of species, like the communities of living organisms, is largely determined by their ecological needs and the characteristics of the spatial distribution of the most important environmental factors that limit their distribution [3]. The overwhelming majority of researchers repeat the long-established opinion that the factors limiting the population dynamics of Zabrus tenebrioides are precipitation, soil moisture, and naturally low temperatures during the wintering period of their worms [8, 11, 14]. However, this question remains highly controversial, since, for example, in the works of E.N. Beletsky and his students' drought is named as one of the limiting factors. If we carefully analyze the plurannual outbreaks of mass reproduction in Ukraine, then all population cycles occurred in the years of droughts from 1863 to 1979 and further 1991-1993 - droughts, 2003-2007 - severe droughts (especially in 2003 and 2007) [1, 4,5,6].

We have made an attempt to analyze the distribution of Zabrus tenebrioides in the space of environmental factors and identify the main limiting factors, as well as to formulate the patterns of distribution of this species. 


\section{MEthodS AND MATERIALS}

Climatic data, information on the habitats of individuals of the species with an indication of geographical coordinates, as well as appropriate software for their processing, analysis and presentation, are necessary $[3,7,9,10]$ in order to simulate the spatial distribution of species by means of GIS. The information on habitats in the Chechen Republic was obtained from the results of our own research, in other regions - based on the analysis of literature data and the GBIF database | Global Biodiversity Information Facility https:/www.gbif.org/ [17]. A Microsoft Excel file with coordinates was converted to a text file (csv). There were a total amount of 279 species finding points.

Field data gathering was carried out from March to October 2002-2016 throughout the entire republic. The method of soil traps, the method of soil samples and manual collection were used for the collection of material. More than 7 thousand specimens were collected. In total, more than 50 biotopes were examined; each of them had about 20 traps. The material was collected 1 time per decade.

During the process of modeling we used the program MaxEnt 3.4.1 and WorldClim climate data (www.worldclim.org) [16], obtained by interpolating the average monthly climate data of global meteorological stations. They are presented as the set of raster images (GRID), each cell of which contains information about a particular climate indicator. For modeling, the bioclimatic variables BIOCLIM listed in Table 1 [9] are of the greatest interest.

TABLE I. BIOCLIMATIC VARIABLES BIOCLIM S

\begin{tabular}{|c|c|}
\hline Code & Bioclimatic parameter \\
\hline BIO1 & Average yearly air temperature \\
\hline BIO2 & Daily average temperature amplitude for each month \\
\hline BIO3 & Isothermality (BIO1/BIO7) $* 100$ \\
\hline BIO4 & Standard temperature deviation \\
\hline BIO5 & Maximum temperature of the warmest month of the year \\
\hline BIO6 & Minimum temperature of the coldest month of the year \\
\hline BIO7 & Annual temperature amplitude (BIO5-BIO6) \\
\hline BIO8 & Average temperature of the most humid year quarter \\
\hline BIO9 & Average temperature of the driest year quarter \\
\hline BIO10 & Average temperature of the warmest year quarter \\
\hline BIO11 & Average temperature of the coldest year quarter \\
\hline BIO12 & Annual rainfall \\
\hline BIO13 & Annual rainfall in the most humid month of the year \\
\hline BIO14 & Annual rainfall in the driest month of the year \\
\hline BIO15 & Rainfall variation coefficient \\
\hline BIO16 & Rainfall in humid year quarter \\
\hline BIO17 & Rainfall in dry year quarter \\
\hline BIO18 & Rainfall in the warmest year quarter \\
\hline BIO19 & Rainfall in the coldest year quarter \\
\hline
\end{tabular}




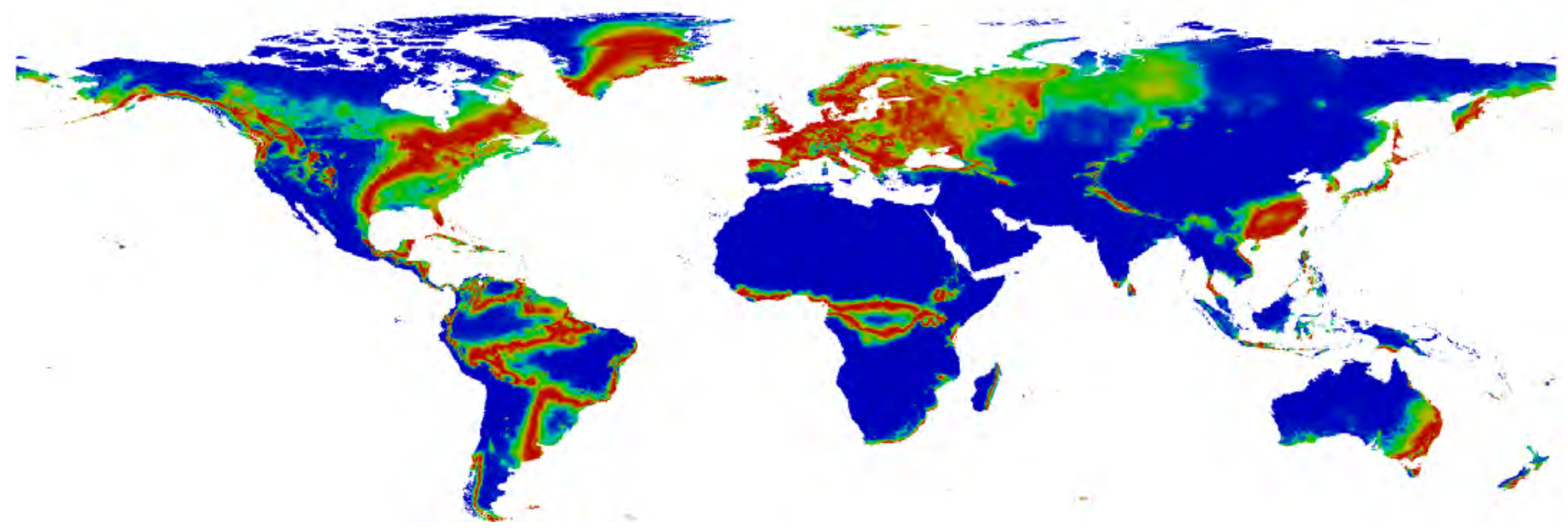

Fig. 2. The suitability of bioclimatic conditions for habitat of Zabrus tenebrioides on the world territory: red and orange areas show the high probability of suitable conditions for the species; green areas show the conditions similar to those in which the species is located; the shades of blue show inappropriate conditionss

The table 2 presents the percentage contribution of each variable to the distribution model of Zabrus tenebrioides. It should be noted that there is a good concordance between the ecologically suitable territory and the habitat of the studied species.

TABLE II. THE CONTRIBUTION OF BIOCLIMATIC INDICATORS (BCI) IN THE FORMATION OF DISTRIBUTION AREAS OF ZABRUS TENEBRIOIDES

\begin{tabular}{|c|c|c|c|}
\hline Code & Bioclimatic parameter & $\begin{array}{c}\text { Percent } \\
\text { contribution }\end{array}$ & $\begin{array}{l}\text { Permutation } \\
\text { importance }\end{array}$ \\
\hline BIO1 & $\begin{array}{l}\text { Average yearly air } \\
\text { temperature }\end{array}$ & 42.6 & 0.2 \\
\hline $\mathrm{BIO} 2$ & $\begin{array}{l}\text { Daily average temperature } \\
\text { amplitude for each month }\end{array}$ & 11.2 & 9.4 \\
\hline $\mathrm{BIO} 3$ & $\begin{array}{c}\text { Isothermality }(\mathrm{BIO} 1 / \mathrm{BIO} 7) \\
* 100\end{array}$ & 10.1 & 37.8 \\
\hline BIO4 & $\begin{array}{c}\text { Standard temperature } \\
\text { deviation }\end{array}$ & 10.1 & +31.5 \\
\hline $\mathrm{BIO5}$ & $\begin{array}{l}\text { Maximum temperature of } \\
\text { the warmest month of the } \\
\text { year }\end{array}$ & 7.7 & 1.5 \\
\hline BIO6 & $\begin{array}{c}\text { Minimum temperature of } \\
\text { the coldest month of the } \\
\text { year }\end{array}$ & 7.5 & 4.1 \\
\hline BIO7 & $\begin{array}{l}\text { Annual temperature } \\
\text { amplitude (BIO5-BIO6) }\end{array}$ & 4.6 & 0.1 \\
\hline $\mathrm{BIO} 8$ & $\begin{array}{c}\text { Average temperature of the } \\
\text { most humid year quarter }\end{array}$ & 2.8 & 0 \\
\hline $\mathrm{BIO9}$ & $\begin{array}{c}\text { Average temperature of the } \\
\text { driest year quarter }\end{array}$ & 1.6 & 4.9 \\
\hline $\mathrm{BIO} 10$ & $\begin{array}{c}\text { Average temperature of the } \\
\text { warmest year quarter }\end{array}$ & 1.2 & 4.3 \\
\hline BIO11 & $\begin{array}{c}\text { Average temperature of the } \\
\text { coldest year quarter }\end{array}$ & 0.4 & 5.3 \\
\hline $\mathrm{BIO} 12$ & Annual rainfall & 0.1 & 0.6 \\
\hline
\end{tabular}

It is shown that out of 19 bioclimatic parameters, contribution of 8 was zero: the amount of precipitation in the coldest quarter of the year, the amount of precipitation in the warmest quarter of the year, the amount of precipitation in the driest quarter of the year, the amount of precipitation in the most humid quarter of the year, the rainfall coefficient variation, the amount of rainfall in the driest month year, the amount of rainfall in the most humid month of the year. It is probable that these factors do not affect the distribution of the species.

The decisive role in the formation of the distribution area belongs to the average annual air temperature (42.6\%). The significant values of the contributions belong to the average daily temperature amplitude for each month, isothermality, standard deviation of temperatures (up to 10\%). For Zabrus tenebrioides, noticeable parameters (up to $7 \%$ ) were the contributions of the maximum temperature of the warmest month of the year and the minimum temperature of the coldest month of the year. It was confirmed in the works of other researchers, who noted a decrease in the average soil temperature at a depth of $20 \mathrm{~cm}$ in the coldest month below -3 - $\mathrm{C}$ [14] as a limiting factor for the spread of Zabrus tenebrioides.

It is known that mass reproduction of geographic and local populations of Zabrus tenebrioides more often occurs in regions of the steppe zone. This is the same for the Chechen Republic and adjacent territories.

As it is shown in figure 3 the territory of the republic is in the zone of climatic optimum. 


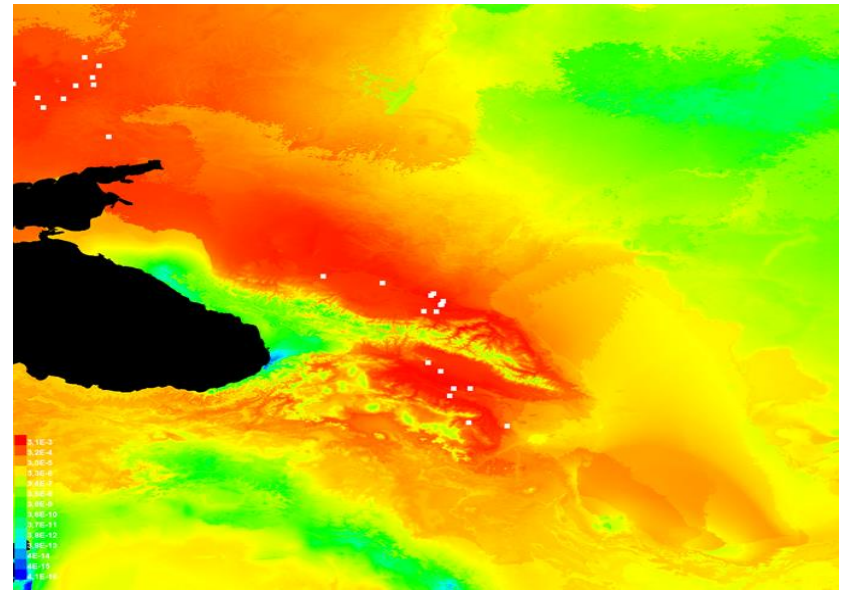

Fig. 3. The suitability of bioclimatic conditions for the habitat of Zabrus tenebrioides in the Caucasus and adjacent territories: white squares are the points where the species are found, red and orange show the high probability of suitable conditions for the species; green show the conditions similar to those in which the species are located; the shades of blue show inappropriate conditions

The results of our own long-term studies of the Karabid fauna of the Chechen Republic (2002-2016) show that this species are found almost everywhere in the lowland territories of the republic. As a dominant species, Zabrus tenebrioides we registered Zabrus tenebrioides in agrocenoses with rye and oats in the steppe zone of the Chechen Republic. The optimum temperature range for normal life of the Zabrus tenebrioides is 20-26 ${ }^{\circ} \mathrm{C}$, with an increase in temperature to $30^{\circ} \mathrm{C}$, the activity of the beetles decreases, and the temperature of $36^{\circ} \mathrm{C}$ and higher leads to their death. During the hot periods, the beetles hide in forest areas, in the cracks of soil and other shelters. According to the results of our research, in summer, the number of Zabrus tenebrioides in agrocenoses decreases, whereas it increases more than threefold in the neighboring forest areas.
Depending on weather conditions, the state of rest lasts on average 20-30 days. With rainfall and the lowering of temperature, the beetles emerge on the soil surface (the second half of August - the beginning of September). In August and September, female beetles lay eggs. During the process of autopsy of female beetles from 6 to 14 eggs were found. Starting from mid-June, the number of generative females in traps increases, the peak of the number of generative individuals falls in August - September.

The worms spend winter in the soil on winter crops and are characterized by poor cold resistance, which limits their habitat. In the spring, the worms feed on winter wheat, after which they leave for the soil. The pupation occurs at the end of April and the pupation phase lasts from 15 to 30 days.

According to V.A. Khilevsky "for the development of worms of the 1 st age the sum of effective temperatures of 345 ${ }^{\circ} \mathrm{C}$, the $2 \mathrm{nd}-375^{\circ} \mathrm{C}$, the $3 \mathrm{rd}-475^{\circ} \mathrm{C}$ is needed and for the development of pupae $-180^{\circ} \mathrm{C}$. With average daily temperatures in September - October of 6-10 ${ }^{\circ} \mathrm{C}$, the development of the 1st age ends in 30-45 days, and the period of active feeding lasts 15-20 days. Then the worm sinks into the soil to a depth of 20-30 cm per molt, which lasts 5-7 days. The molted worms remain inactive for another 5-8 days, and then begin to feed actively. Depending on weather conditions, the developmental period of the 2 nd and $3 \mathrm{rd}$ (most harmful) age of worms lasts from 30 to 50 days, and the period of active feeding lasts 15-20 days. Then the worm again goes to molt" [14].

As several researchers have noted, the sum of effective temperatures is a determining factor for many organisms.

The sum of effective temperatures is the total amount of heat received to complete the life cycle of animals from an egg to an adult. We used the QGIS program in order to analyze the dependence of the spatial distribution of Zabrus tenebrioides on total effective temperatures.

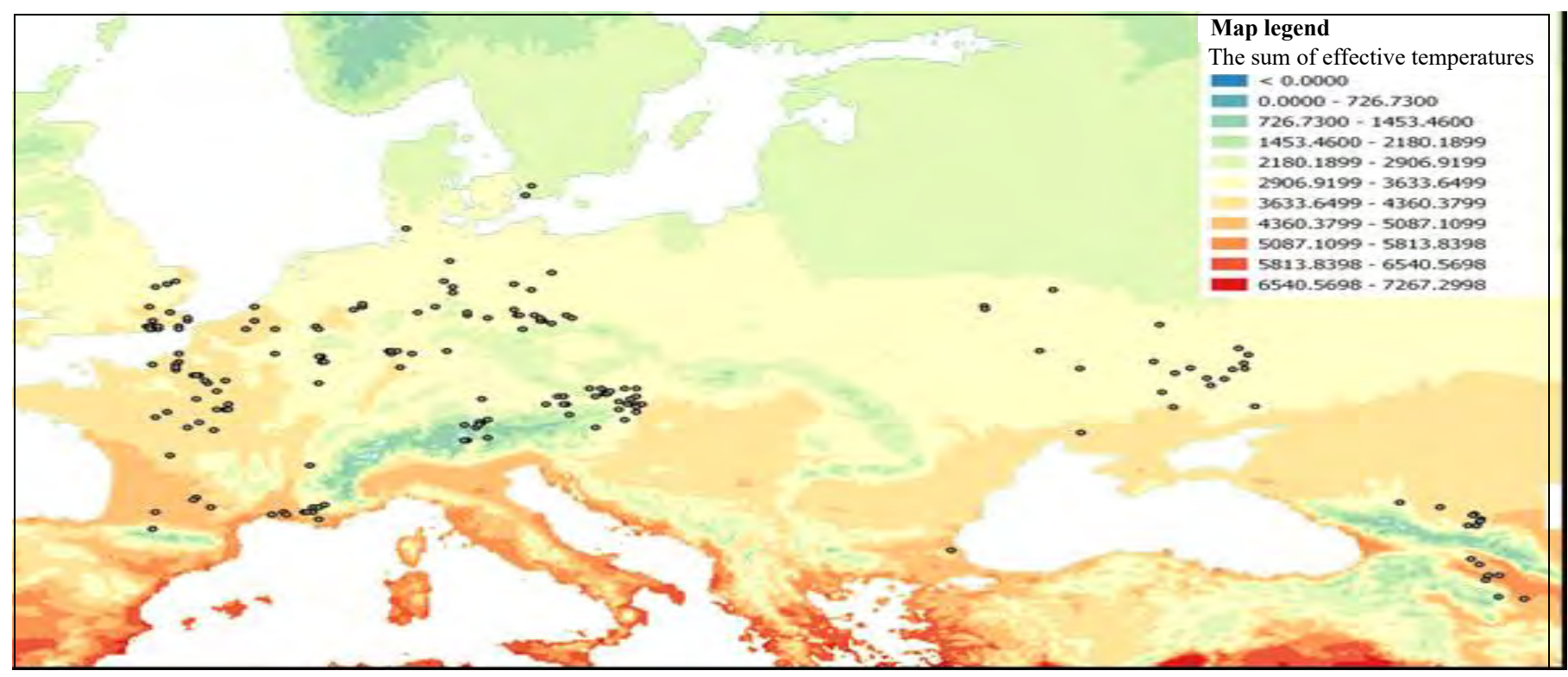

Fig. 4. The dependence of spatial distribution of Zabrus tenebrioides on the sum of effective temperatures 
According to the map that we obtained, the locations of Zabrus tenebrioides are located in the zone of temperate continental climate, where the sums of effective temperatures lie in the range of $2907-36334^{\circ}$ C. 50870 C). It is possible that higher amounts of effective temperatures are compensated by increased humidity.

\section{CONCLUSION}

As the result, according to the analysis, the main climatic factors affecting the spread of Zabrus tenebrioides are the average annual air temperature, the average daily temperature amplitude for each month, isothermality, the standard deviation of temperatures, the maximum temperature of the warmest month. The boundaries of the range obtained during the research (Fig. 2) mostly correspond to the data of literary sources.

The best climatic conditions for the species are found in western and central Europe, on the eastern coast of North America, in the central and eastern part of South America, central Africa, in the south-eastern part of Australia, western and southern China, central Russia, Belarus, Ukraine, Kazakhstan, Iran, Turkmenistan, Uzbekistan (70-90\%).

The points of collection and observation in the Chechen Republic are among the territories close to the climatic optimum (50-70\%), which explains the relatively high abundance of this species. As a dominant species, we registered Zabrus tenebrioides in agrocenoses with rye and oats in the steppe zone of the Chechen Republic. The optimum temperature range for normal life of Zabrus tenebrioides is $20-26^{\circ} \mathrm{C}$. The generative females begin to fall into the traps from June, the peak of their numbers occur in AugustSeptember. The worms spend winter in the soil. For the development of 1 st age of worms, the sum of effective temperatures of $345^{\circ} \mathrm{C}$, of the $2 \mathrm{nd}-375^{\circ} \mathrm{C}$, of the $3 \mathrm{rd}-$ $475^{\circ} \mathrm{C}$, pupae $-180^{\circ} \mathrm{C}[14]$ is needed.

The analysis of the dependence of spatial distribution of Zabrus tenebrioides on total effective temperatures showed that the points of location of this species are confined to zones of temperate continental climate with the sums of effective temperatures in the range of $2907-36340 \mathrm{C}$

\section{References}

[1] N. Al Dzhagub, Patterns of long-term population dynamics and the forecast of mass reproduction of ground beetle, extended abstr. of thesis for candidate of biol. science, Kharkov, 1996, p. 21.
[2] K.S. Artohin, A.V. Grinko, "Features of biology and harmfulness of the bug of a harmful bug and grain ground beetle in southern Russia", Proceedings of higher educational institutions. North Caucasus region. Natural Sciences, vol. 5, pp. 61-62, 2008.

[3] A. N. Afonin, Yu. V. Sokolova, Ecological-geographical analysis and modeling of the distribution of biological objects using GIS, handbook. SPb: Izd-vo VVM, 2018, p. 121.

[4] E.N. Beleckij, " Phytosanitary forecasting in Ukraine: history, methodology, ways to improve", Plant protection and quarantine, vol. 12, 2015, pp. 14-19.

[5] E. N. Beleckij, Mass reproduction of insects. History, theory, forecasting. Kharkov: Majdan, 2011, p.172.

[6] E. N. Beleckij, S. V. Stankevich, Polycyclicity, synchronicity and nonlinearity of the population dynamics of insects and problems of forecasting. Vena: Premier Publishing, 2018, p.138.

[7] I.N. Bolotov, A.A. Frolov, "Modeling of the area and analysis of the contribution of factors to the climate niche Parnassius Mnemosyn L. 1758 (Lepi doptera : Papilionidae)", Arctic Evironmental Research, vol. 4, 2015, pp. 56-67.

[8] D.A. Guliev, "Harmfulness of bread ground beetle", Plant protection and quarantine, vol. 5, 2007, pp. 39-40.

[9] A.V. Egoshin, "Modeling the spatial distribution of species using geographic information systems", retrieved from: https://www.dataplus.ru/news/arcreview/detail.php?ID=9997\&SECTIO N_ID $=281$

[10] O. V. Kukushkin, I. V. Doronin, YU. A. Krasilenko, "Analysis of the distribution of the juniper Arceuthobia ohysedri and its main owner, Uniperus deltoides in the Crimea, using geo-information technologies", Russian Journal of Ecosystem Ecology, vol. 2 (1)., 2017, DOI 10.21685/2500-0578-2017-1-5.

[11] T.I. Skrebcova, E.V. Chenikalova et al., "Grain ground beetle on winter crops of Stavropol", Plant protection and quarantine, vol. 8, 2011, p. 15.

[12] L.I. Trepashko, S.V. Bojko, "Invasion of common ground beetle on the territory of Belarus", Plant protection and quarantine, vol. 11, 2016, pp. 32-35.

[13] V. P. Fedorenko, "Phytosanitary condition of Ukraine's agrocenoses", Plant protection and quarantine, vol. 4, 2012, pp. 48-52.

[14] V.A. Hilevskij, "Grain ground beetle in the North Caucasus", Plant protection and quarantine, vol. 8, 2013, pp.21-23,.

[15] E. V.Chenikalova, I. D.Pentyk, A. V. Alekseev "The effectiveness of the fight with ground beetle", Plant protection and quarantine, vol. 4, 2009 pp. 42-43.

[16] WorldClim - Global Climate Data, retrieved from: http://www.worldclim.org/

[17] GBIF, Global Biodiversity Information Facility, retrieved from: https://www.gbif.org/

[18] J. Elith, S. J. Phillips, T. Hastie, M. Dudík Yu. En Chee, C. J. Yates, "A statistical explanation of MaxEnt for ecologists", retrieved from: https://doi.org/10.1111/j.1472-4642.2010.00725.x 